\title{
IMPLEMENTASI FUNGSI MANAJEMEN PADA PENGELOLAAN PROGRAM BANTUAN OPERASIONAL PAUD DI MASA PANDEMI COVID-19
}

\author{
Ach. Baidowi \\ Sekolah Tinggi Ilmu Dakwah dan Komunikasi Islam Al-Mardliyyah \\ Pamekasan \\ achbaidowi16@gmail.com
}

\begin{abstract}
Management of organizational operational assistance funds is an effort to regulate the use of schools operational assistance funds so that their use is in accordance with school needs. The purpose of the research to describe the process of planning, organizing, implementing and controlling of operational assistance funds. The research approach is qualitative with data collection techniques namely interviews, observation and documentation. data analysis techniques with condensation, data presentation and drawing conclusions. The results show that planning is an activity of planning the use of operational assistance funds in schools, the organizing is the formatting of managers and grouping the use of operational assistance funds, implementation, namely the use of operational assistance funds for schools and controlling is checking the use of operational assistance funds.
\end{abstract}

Keywords: operational assistance funds, management function, covid-19 pandemic, early childhood education

\begin{abstract}
Abstrak
Pengelolaan Bantuan Operasional Penyelenggaran merupakan usaha mengatur penggunaan dana bantuan operasional penyelenggaraan agar penggunaannya sesuai dengan kebutuhan sekolah. Tujuan penelitian untuk mendeskripsikan proses perencanaan, pengorganisasian, pelaksanaan dan pengontrolan pengelolaan dana Bantuan Operasional Penyelenggaraan. Pendekatan penelitian adalah kualitatif dengan teknik pengumpulan data yaitu wawancara, observasi dan dokumentasi serta teknik analisis data dengan kondensasi, penyajian data dan penarikan kesimpulan. Hasil menunjukkan perencanaan merupakan kegiatan merencanakan penggunaan dana bantuan operasional penyelenggaraan di sekolah, sedangkan pengorganisasian merupakan pembentukan pengelola dan pengelompokan penggunaan dana Bantuan Operasional Penyelenggaraan. Pelaksanaan yaitu penggunaan dana Bantuan Operasional Penyelenggaraan untuk sekolah dan pengontrolan merupakan pengecekan penggunaan dana Bantuan Operasional Penyelenggaraan.
\end{abstract}

Kata Kunci: bantuan operasional penyelenggaraan, fungsi manajemen, pandemi covid-19, pendidikan anak usia dini 


\section{Pendahuluan}

Pendidikan merupakan proses pemberian dan pembekalan ilmu berupa pengetahuan, sikap, dan keterampilan kepada seseorang agar dapat meningkatkan dan mengembangkan potensi dan kompetensi yang dimilikinya. Pendidikan dapat dilakukan oleh siapa saja, di mana saja, kapan saja, dengan apa saja dan dari mana saja sumbernya. Proses pendidikan sejatinya sudah didapatkan oleh manusia sejak mereka lahir, misalnya pendidikan yang diberikan oleh orang tua tentang melatih keterampilan berbicara pada anak, pendidikan tentang melatih sikap anak dan lain sebagainya. Pendidikan merupakan upaya menuntuk seorang anak yang dilakukan sejak lahir sampai anak tersebut tumbuh dewasa secara jasmani ataupun rohani sehingga mereka dapat berinteraksi dengan orang serta lingkungan di sekitarnya. ${ }^{1}$

Lembaga Pendidikan Anak Usia Dini atau PAUD adalah lembaga pendidikan yang khusus diperuntukan untuk mendidik anak mulai dari umur 0 sampai 6 tahun. PAUD dapat didirikan oleh pemerintah ataupun oleh swasta dengan tujuan menjadi wadah bagi anak usia dini serta membantu dan orang tua untuk mengembangkan potensi dan kompetensi anak sesuai dengan tumbuh kembang anak. Proses pendidikan pada lembaga PAUD memfokuskan diri pada pengembangan spiritual, sikap, mental dan perilaku anak agar dapat berkembang sesuai dengan kebutuhan psikologis, kognitif dan motorik anak. PAUD merupakan lembaga pendidikan yang proses pendidikannya untuk membantu melatih dan mengembangkan sikap dan motorik pada anak. ${ }^{2}$

Bantuan Operasional Penyelenggaraan (BOP) pendidikan merupakan bentuk usaha dari pemerintah untuk membantu penyelenggaraan pendidikan pada lembaga PAUD agar bisa berjalan baik dan bermutu. BOP merupakan bantuan berupa pemberian uang kepada lembaga PAUD di mana besaran dana yang diberikan disesuaikan dengan jumlah siswa yang sudah terverifikasi dalam Data Pokok Pendidikan (Dapodik) PAUD. Program BOP memiliki tujuan untuk membiayai seluruh keperluan dan kebutuhan operasional PAUD agar proses pendidikan pada lembaga PAUD dapat berjalan dengan baik dan berkualitas. Dana BOP selama pandemi Covid-19 dipergunakan untuk membiayai pembeliatan alat dan bahan kebersihan sekolah untuk mencegah penyebaran virus Covid-19 serta dipergunakan untuk membiayai proses belajar mengajar yang dilakukan secara jarak jauh (daring) antara guru dan murid.

Dana BOP dalam penggunaannya perlu diatur dan dikelola dengan sangat baik oleh lembaga PAUD, tujuannya agar dana tersebut dapat dimanfaatkan secara maksimal serta dapat memberi dampak yang positif terhadap peningkatan proses pendidikan (belajar pembelajaran) pada lembaga PAUD selama pandemi Covid-19 ini. Untuk mengatur dan mengelola dana BOP PAUD tersebut, diperlukan suatu pola atau seni pengaturan yang bersifat terarah, sistematis, terorganisir dan transparan dalam pengelolaanya. Salah satu upaya yang dapat dilakukan dengan menggunakan pendekatan fungsi manajemen dalam mengelola dana BOP tersebut. Fungsi

1 Nurkholis, "Pendidikan Dalam Upaya Memajukan Teknologi," Jurnal Kependidikan 1, no. 1 (2013):

$24-44$ http:// ejournal.iainpurwokerto.ac.id/index.php/jurnalkependidikan/article/download/530 $/ 473 /$.

2 Achmad Baidowi, "Implementasi Kebijakan Program Bantuan Operasional Penyelenggaraan Pendidikan Pada Masa Pandemi Covid-19," Jambura Journal of Educational Management 1, no. 2 (2020): 84-102. 
manajemen tersebut adalah perencanaan, pengorganisasi, pelaksananaan dan pengontrolan yang sangat membantu para pengelola dana BOP dalam hal : pertama, pematangan perkiraan penggunaan dana BOP melalui kegiatan perencanaan; kedua, pembagian pekerjaan yang terorganisir melalui kegiatan pengorganisasian; ketiga, ketepatan penggunaan melalui kegiatan pelaksanaan; dan keempat ketransparanan penggunaan dana melalui kegiatan pengontrolan dana BOP.

Adapun tujuan dari penelitian ini adalah untuk mendeskripsikan dan menjelaskan masing-masing fungsi manajemen pada proses pengelolaan dana BOP oleh lembaga PAUD di antaranya untuk mendeskripsikan dan menjelaskan proses perencanaan pengelolaan dana BOP, mendeskripsikan dan menjelaskan proses pengorganisasian pengelolaan dana BOP, mendeskripsikan dan menjelaskan pelaksanaan pengelolaan dana BOP serta mendeskripsikan dan menjelaskan proses pengontrolan pengelolaan dana BOP.

\section{Tinjauan Literatur}

A. Fungsi Manajemen

Manajemen merupakan pola atau seni pengaturan pra-pelaksanaan sesuatu kegiatan, aktivitas, atau pekerjaan yang dilakukan oleh seseorang atau organisasi agar berjalan dengan tepat dan terarah. Manajemen juga dapat diartikan sebagai pengaturan segala sesuatu yang dibutuhkan oleh seseorang atau organisasi sebelum melaksanakan suatu program kegiatan atau aktivitas yang telah direncanakan sebelumnya. Secara umum, manajemen mencakup beberapa fungsi yang dapat digambarkan sebagai berikut:

\section{Gambar 1}

\section{Aktivitas Fungsi Manajemen}

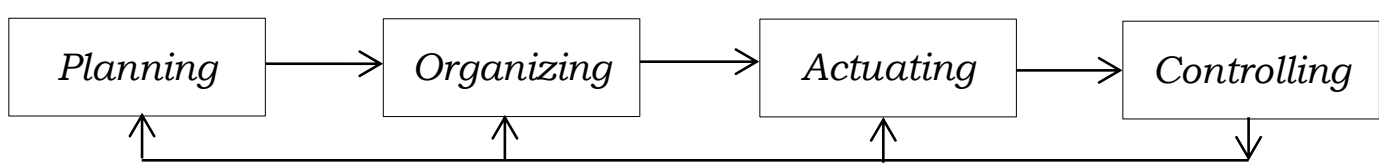

Berdasarkan gambar 1, maka masing-masing fungsi manajemen tersebut dapat dijelaskan sebagai berikut:

1. Perencanaan

Perencanaan adalah proses mempersiapkan secara sistematis kegiatan yang akan dikerjakan pada waktu yang akan mendatang untuk mencapai tujuan dan sasaran yang telah ditentukan. ${ }^{3}$ Perencanaan juga dapat diartikan sebagai proses pengambilan keputusan atas sejumlah alternatif mengenai sasaran dan cara yang akan dilaksanakan di masa mendatang untuk mecapai tujuan yang dikehendaki yang dilakukan secara sistematis dan berkesinambungan.4 Tujuan perencanaan adalah agar program, aktivitas, kegiatan pendidikan dapat berjalan terarah, teratur, sistematis

3 Muhammad Zaini, "Implementasi Fungsi Manajemen dalam Pengembangan Pendidikan Multikultural," Edu Islamika 4, no. 2 (2013): 281-315.

${ }^{4}$ Husaini Usman, Manajemen Teori, Praktik, dan Riset Pendidikan, (Jakarta: Bumi Aksara, 2011), 66. 
dan tidak tumpang tindih; untuk memilih tindakan-tindakan yang sesuai dengan situasi dan kondisi pendidikan; untuk memilih tindakan prioritas yang didahulukan pelaksanaannya; untuk memudahkan pemilihan tenaga pelaksana yang berkompeten dan relevan; serta untuk memudahkan evaluasi dan pengawasan (Zaini, 2013). ${ }^{5}$ Adapun beberapa kegiatan yang dilakukan dalam proses perencanaan antara lain:

a. Menjelaskan dan menetapkan tujuan yang akan dicapai

b. Memperkirakan keadaan yang akan mendatang

c. Memperkirakan kondisi pekerjaan yang dilakukan

d. Memilih tugas sesuai dengan tujuan

e. Membuat rencana strategis bagi organisasi

f. Membuat kebijakan, prosedur, standar, dan metode melakukan pekerjaan

g. Mengubah rencana sesuai hasil pengawasan atau penilaian. ${ }^{6}$

2. Pengorganisasian

Pengorganisasian adalah proses penentuan, pengelompokkan, dan pengaturan berbagai aktivitas yang diperlukan untuk mencapai tujuan. ${ }^{7}$ Pengorganisasian diartikan sebagai penataan, pengelompokkan, pendistribusian tugas dan tanggungjawab serta wewenang pada masingmasing perangkat untuk menjadi kolektivitas yang dapat digerakkan sebagai teamwork dalam usaha mencapai tujuan. ${ }^{8}$ Pengorganisasian sebagai proses pembagian tugas kerja menjadi beberapa unit kerja dengan tujuan untuk mempermudah dan mengorganisir tugas kerja implementasi yang harus diselesaikan oleh organisasi pendidikan. ${ }^{9}$ Sehingga dapat dijelaskan bahwa tahap pengorganisasian mengarah pada kegiatan pengaturan dan penetapan siapa yang menjadi pelaksana, penetapan anggaran, penetapan sarana dan prasarana, penetapan tata kerja, penetapan manajemen pelaksanaan termasuk pola kepemimpinan dan koordinasi pelaksanaan kebijakan. ${ }^{10}$

Mengorganisasikan merupakan proses menggabungkan orang-orang berdasarkan pembagian tugas, wewenang, dan tanggungjawab secara terperinci berdasarkan bagian dan bidang sehingga terintegrasikan hubungan kerja yang sinergis, koperatif, harmonis dan seirama dalam mencapai tujuan. ${ }^{11}$ Pengorganisasian merupakan aktivitas pembagian tugas dan tanggungjawab kepada seluruh anggota organisasi yang

5 Muhammad Zaini, "Implementasi Fungsi Manajemen dalam Pengembangan Pendidikan Multikultural."

6 Awaluddin and Hendra, "Fungsi Manajemen Dalam Pengadaan Infrastruktur Pertanian Masyarakat Di Desa Watatu Kecamatan Banawa Selatan Kabupaten Donggala."

7 Awaluddin and Hendra.

8 Muhammad Zaini.

9 Baidowi, "Implementasi Kebijakan Program Bantuan Operasional Penyelenggaraan Pendidikan Pada Masa Pandemi Covid-19 Achmad Baidowi."

10 Joko Widodo, Analisis Kebijakan Publik: Konsep dan Aplikasi Analisis Proses Kebijakan Publik, (Malang: Bayumedia Publishing, 2012), 91.

11 Saefullah U, Manajemen Pendidikan Islam, (Bandung: Pustaka Setia, 2012), 22. 
didasarkan pada profesionalitas, tugas dan fungsi tenaga pada organisasi. ${ }^{12}$ Kegiatan pengorganisasian meliputi:

a. Membagi pekerjaan ke dalam tugas operasional

b. Mengelompokkan tugas ke dalam posisi-posisi secara operasional

c. Menggabungkan jabatan operasional ke dalam unit yang saling berkaitan

d. Memilih dan menempatkan orang untuk suatu pekerjaan yang sesuai

e. Menjelaskan persyaratan dari setiap jabatan

f. Menyesuaikan wewenang dan tanggungjawab bagi anggota

g. Menyediakan berbagai fasilitas untuk pegawai

h. Menyelaraskan organisasi sesuai petunjuk. ${ }^{13}$

3. Pelaksanaan

Pelaksanaan merupakan tindakan yang dilakukan oleh seseorang untuk mengawali dan melanjutkan kegiatan yang ditetapkan oleh unsur perencanaan dan pengorganisasian agar tujuan dapat tercapai. ${ }^{14}$ Pelaksanaan sebagai tindakan yang dilakukan oleh individu atau kelompok pemerintah atau swasta yang diarahkan pada pencapain tujuan yang telah ditentukan. ${ }^{15}$ Pelaksanaan juga dapat diartikan sebagai serangkaian kegiatan yang dilakukan oleh organisasi pendidikan untuk menerapkan program pendidikan yang dibuat oleh Kemeterian Pendidikan, Dinas Pendidikan, dan/atau oleh organisasi pendidikan lainnya. ${ }^{16}$ Sehingga pelaksanaan berfungsi untuk menggerakkan atau merangsang anggota kelompok untuk melaksankan tugas masingmasing. ${ }^{17}$ Kegiatan dalam pelaksanaan atau penggerakan terdiri atas tindakan sebagai berikut:
a. Melakukan partisipasi terhadap keputusan, tindakan dan perbuatan
b. Mengarahkan orang lain dalam bekerja
c. Memotivasi anggota
d. Berkomunikasi secara efektif
e. Meningkatkan anggota agar memahami potensinya secara penuh
f. Memberi imbalan penghargaan yang sesuai terhadap pekerjaan. ${ }^{18}$

\footnotetext{
12 Fathul Maujud, "Implementasi Fungsi-Fungsi Manajemen Dalam Lembaga Pendidikan Islam (Studi Kasus Pengelolaan Madrasah Ibtidaiyah Islahul Muta'allim Pagutan)," Jurnal Penelitian Keislaman 14, no. 1 (2018): 30-50, https://doi.org/10.20414/jpk.v14i1.490.

13 Awaluddin and Hendra, "Fungsi Manajemen Dalam Pengadaan Infrastruktur Pertanian Masyarakat Di Desa Watatu Kecamatan Banawa Selatan Kabupaten Donggala."

14 Awaluddin and Hendra.

15 Solichin Mujianto, "Implementasi Kebijakan Pendidikan Dan Peran Birokrasi," Studi Islam 6, no. 2 (2015): 148-78.

16 Baidowi, "Implementasi Kebijakan Program Bantuan Operasional Penyelenggaraan Pendidikan Pada Masa Pandemi Covid-19."

17 Muhammad Zaini, "Implementasi Fungsi Manajemen dalam Pengembangan Pendidikan Multikultural."

18 Awaluddin and Hendra.
} 
4. Pengontrolan

Pengontrolan merupakan upaya mengadakan penilaian dan koreksi terhadap hal yang telah dilakukan bawahan sehingga dapat diarahkan pada ajalan yang benar sesuai dengan tujuan.19 Pengontrolan sebagai proses penentuan apa yang harus dicapai yaitu standar, apa yang sedang dilakukan yaitu pelaksanaan, menilai pelaksanaan sesuai dengan rencana yaitu selaras dengan standar. ${ }^{20}$ Pengontrolan berarti meneliti dan mengawasi agar tugas dapat dilakukan dengan baik dan sesuai dengan peraturan yang ada. ${ }^{21}$ Mengontrol berarti mengawasi atau memantau tugas yang dilaksanakan sekaligus memberikan evaluasi dan perbaikan sehingga pelaksanaan tugas sesuai dengan rencana yang ditetapkan. ${ }^{22}$ Kegiatan atau aktivitas dalam pengontrolan sebagai berikut:

a. Membandingkan hasil pekerjaan dengan rencana

b. Menilai hasil pekerjaan dengan standar hasil kerja

c. Membuat media pelaksanaan secara tepat

d. Memberitahukan media pengukur pekerjaan

e. Memindahkan data secara rinci untuk melihat perbandingan dan penyimpangan

f. Membuat saran dan tindakan perbaikan

g. Memberitahukan anggota yang bertanggungjawab terhadap pemberian penjelasan

h. Melaksanakan pengawasan sesuai dengan petunjuk hasil pengawasan. ${ }^{23}$

\section{B. Pendidikan Anak Usia Dini}

Pendidikan anak usia dini adalah upaya pembinaan yang ditujukan kepada anak sejak lahir sampai usia enam tahun melalui pemberian rangsangan pendidikan dalam membantu pertumbuhan dan perkembangan jasmani dan rohani anak. ${ }^{24}$ PAUD adalah Lembaga pendidikan yang memiliki fasilitas untuk mengoptimalkan potensi yang dimiliki anak dengan tujuan mengembangkan seluruh potensi anak agar menjadi manusia yang seutuhnya. ${ }^{25}$ PAUD diartikan sebagai wahana untuk bermain sambil belajar dengan penuh keceriaan dan kebebasan sehingga anak dapat mengekspresikan, mengembangkan bakat, minat

19 Maujud, "Implementasi Fungsi-Fungsi Manajemen Dalam Lembaga Pendidikan Islam (Studi Kasus Pengelolaan Madrasah Ibtidaiyah Islahul Muta'allim Pagutan)."

20 Awaluddin and Hendra, "Fungsi Manajemen Dalam Pengadaan Infrastruktur Pertanian Masyarakat Di Desa Watatu Kecamatan Banawa Selatan Kabupaten Donggala."

${ }^{21}$ Saefullah U, Manajemen Pendidikan Islam.

22 Muhammad Zaini, "Implementasi Fungsi Manajemen dalam Pengembangan Pendidikan Multikultural."

23 Awaluddin and Hendra, "Fungsi Manajemen Dalam Pengadaan Infrastruktur Pertanian Masyarakat Di Desa Watatu Kecamatan Banawa Selatan Kabupaten Donggala."

${ }^{24}$ Undang Undang Nomor 20 Tahun 2003 tentang Sistem Pendidikan Nasional, Pasal 1 ayat 14

${ }^{25}$ Qudsyi Hazhira, "Optimalisasi Pendidikan Anak Usia Dini Berdasarkan Pembelajaran Yang Berbasis Perkembangan Otak," Buletin Psikologi 18, no. 2 (2010): 91-111, https://doi.org/10.22460/ceria.v2i2.p29-36.

$$
\begin{array}{ll|l|l}
\text { Vol. } 1 \text { No. } 2 \text { (Desember, } 2020) & \text { Page } 146
\end{array}
$$


dan kreativitasnya sekaligus menambah pengetahuan, keterampilan dan pengembangan sikap perilaku anak. ${ }^{26}$ Sehingga dapat dijelaskan bahwa PAUD merupakan salah satu bentuk penyelenggaraan pendidikan yang menitikberatkan pada pengembangan nilai agama dan moral dan pengembangan sosial emosional, kemandirian dan kemampuan dasar yang meliputi pengembangan bahasa, kognitif dan fisik motorik pada anak. ${ }^{27}$

Tujuan dari Pendidikan Anak Usia Dini (PAUD) adalah menanamkan dan mengembangkan keimanan dan ketakwaan anak; menanamkan sikap disiplin, anak mampu mengelola keterampilan tubuh termasuk gerakan yang mengontrol gerakan tubuh, gerakan harus, gerakan kasar dan penerimaan rangsangan sensorik; meningkatkan kecakapan anak untuk menunjukkan sesuatu yang berkaitan dengan penggunaan fisik dan mental anak; serta melatih dan mengembangkan kepekaan anak terhadap sesuatu. Sedangkan prinsip pelaksanaan PAUD adalah harus berorientasi pada kebutuhan anak, kegiatan bermain merupakan media belajar yang baik bagi anak, pendekatan pembelajaran berpusat pada anak, menggunakan pendekatan konstruktivisme dalam pembelajaran, harus merangsang kreativitas dan inovatif anak, lingkungan belajar harus kondusif, menggunakan pembelajaran terpadu, mengembangkan tematik, menggunakan berbagai media dan sumber belajar, serta harus dapat mengembangkan berbagai kecakapan hidup bagi anak (Wijana, 2014). ${ }^{28}$

C. Bantuan Opersional Penyelenggaraan (BOP)

Bantuan Operasional Penyelenggaraan atau BOP merupakan program pemberian uang dari Kemeterian Pendidikan untuk membantu dan mendukung lembaga PAUD dalam melaksanakan proses pendidikan yang diberikan setiap satu tahun sekali. BOP dikeluarkan untuk membantu penyediaan pendanaan biaya operasional pembelajaran PAUD. ${ }^{29}$ Sehingga BOP diartikan sebagai program pemberian dana atau uang khusus untuk lembaga PAUD yang besaran dananya berdasarkan pada jumlah siswa yang terdapat pada lembaga PAUD. 30 BOP merupakan salah satu bantuan yang membantu penyediaan pembiayaan biaya operasional bagi satuan PAUD untuk mendukung kegiatan operasional pendidikan dan meringankan biaya pendidikan bagi orang tua dalam upaya

26 Suharti, "Manajemen Pendidikan Anak Usia Dini (PAUD) Dalam Rangka Meningkatkan Mutu Pembelajaran (Studi Pada PAUD Negeri Pembina Curup Dan PAUD Pertiwi Kabupaten Rejang Lebong)," Tadbir: Jurnal Studi Manajemen Pendidikan 2, no. 1 (2018): 51, https://doi.org/10.29240/jsmp.v2i1.397.

${ }^{27}$ Rosyid Ridho, Markhamah, and Darsinah, "Pengelolaan Pembelajaran Paud Di KB 'Cerdas' Kecamatan Sukorejo Kabupaten Kendal," Penelitian Humaniora 16, no. 02 (2015): 59-69, https://doi.org/10.31102/wacanadidaktika.v5i02.63.

28 Wijana Didarmi D, "Konsep-Konsep Dasar Pendidikan Anak Usia Dini," in Didaktika, Vol. 20 No. 2 Februari 2014, vol. 5, 2014, 329-33, https://www.google.com/url?sa=t\&source=web\&rct=j\&url=http:// repository.ut.ac.id $/ 4724$ / 1 PAUD4409-M1.pdf\&ved=2ahUKEwi7vZGBk-

7rAhWWSHOKHZN4BzMQFjALegQIDRAC\&usg=AOvVaw3FE1r6418LV9BiL17K2dkL.

${ }^{29}$ Permendikbud Nomor 13 Tahun 2020 tentang Petunjuk Teknis Dana Alokasi Khusus Non Fisik BOP, PAsal 1, Ayat 4.

30 Baidowi, "Implementasi Kebijakan Program Bantuan Operasional Penyelenggaraan Pendidikan Pada Masa Pandemi Covid-19." 
mengikutsertakan anakanya dalam layanan pendidikan yang bermutu. ${ }^{31}$ Tujuan program BOP adalah membantu penyediaan biaya operasional non-personalia bagi peserta didik, meringankan beban biaya pendidikan bagi masyarakat dalam mengikuti layanan PAUD, meningkatkan peran serta masyarakat dalam penyelenggaraan dan pengembangan PAUD. ${ }^{32}$ Penggunaan dana BOP adalah sebagai berikut:

a. Memenuhi komponen pembelajaran dan bermain PAUD, antara lain untuk:

1) Pembelian bahan pembelajaran peserta didik yang dibutuhkan sesuai dengan kegiatan tematik seperti buku gambar, kertas lipat, cat air, spidol, pensil dan lain sebagainya

2) Penyediaan Alat Bermain Edukatif (APE) dalam ruangan sesuai dengan kebutuhan satuan pendidikan

3) Penyediaan alat mengajar bagi pendidik seperti papan tulis, spidol, buku tulis, kertas dan lain sebagainya

b. Memenuhi komponen kegiatan pendukung PAUD, antara lain untuk:

1) Penyediaan makanan tambahan untuk peserta didik dalam rangka mendukung pemenuhan gizi dan kesehatan anak

2) Pembelian alat deteksi dini tumbuh kembang anak, pembelian obat-obatan ringan, dan isi kotak Pertolongan Pertama pada Kecelakaan (P3K)

3) Kegiatan pertemuan dengan orang tua/wali murid (kegiatan parenting)

4) Memberi transport tenaga pendidik, seperti transport untuk menghadiri kegiatan pembelajaran, pertemuan gugus, atau menghadiri kegiatan peningkatan kapasitas pendidik

5) Penyediaan buku administrasi, seperti buku induk peserta didik, buku laporan perkembangan anak, buku inventaris dan lain sebagainya

c. Memenuhi komponen kegiatan PAUD lainnya, antara lain untuk:

1) Perawatan sarana dan prasarana PAUD, seperti perbaikan dan pengecatan ringan, penggantian lampu, pegangan pintu, perbaikan meja dan kursi dan lain sebagainya

2) Penyediaan alat-alat publikasi PAUD, seperti brosur, poster, papan nama dan lain sebagainya.

3) Langganan listrik, telepon/internet dan air. ${ }^{33}$

31 Putri Sianturi et al., "Sistem Pendukung Keputusan Penentuan Penerima Bantuan Operasional Penyelengaraan (BOP) Paud (Pendidikan Anak Usia Dini) Menerapkan Metode ELECTRE (Studi Kasus: Dinas Pendidikan Kabupaten Simalungun)," KOMIK (Konferensi Nasional Teknologi Informasi Dan Komputer) I, no. 1 (2017): 20-26.

${ }^{32}$ Permendikbud Nomor 13 Tahun 2020 tentang Petunjuk Teknis Dana Alokasi Khusus Non Fisik BOP, Pasal 3.

33 Permendikbud Nomor 13 Tahun 2020 tentang Petunjuk Teknis Dana Alokasi Khusus Non Fisik BOP. 


\section{Metode}

Penelitian ini menggunakan pendekatan penelitian kualitatif di mana hasil penelitian disajikan dalam bentuk kata-kata dan kalimat yang disusun secara singkat dan jelas. Jenis penelitian menggunakan studi kasus di mana pengelolaan dana BOP dianggap sebagai suatu kasus yang perlu diteliti secara mendalam. Penelitian dilakukan pada PAUD Nur-Masithah Kecamatan Sampang, di mana satu kepala sekolah, satu bendahara BOP dan dua guru PAUD sebagai informan dalam penelitian ini.

Metode pengumpulan data dilakukan melalui wawancara, observasi, dan dokumentasi. Sedangkan metode keabsahan data dilakukan dengan cara pertama triangulasi teknik yaitu data yang diperoleh diuji berdasarkan teknik pengumpulan data yaitu dengan wawancara, dokumentasi dan observasi. Triangulasi teknik dilakukan dengan mengecek data yang didapat dengan menggunakan berbagai teknik yang berbeda. ${ }^{34}$ Kedua, triangulasi sumber yaitu data yang diperloleh dari sumber data (informan) satu dicocokkan dengan sumber data (informan) yang lain. Triangulasi sumber yaitu pengecekan data hasil penelitian yang dilakukan kepada berbagai sumber penelitian. ${ }^{35}$ Ketiga, uji konfirmabilitas atau uji kepastian yaitu hasil penelitian telah mendapat validasi dari sumber (informan) penelitian. Data hasil penelitian dikatakan sah jika sudah disepekati oleh seluruh sumber data atau informan penelitian. ${ }^{36}$

Tahap-tahap analisis data dalam penelitian ini antara lain: pertama, kondensasi data yaitu memilih data hasil penelitian sesuai dengan fokus penelitian. Data yang didapat peneliti yang berjumlah cukup banyak, kemudian data tersebut dirangkum dan dipilih hal-hal pokoknya sesuai dengan tema penelitian. ${ }^{37} \mathrm{Kedua}$, penyajian data yaitu menampilkan data dalam bentuk kalimat yang singkat, padat, dan jelas. Penyajian data dapat dilakukan dalam bentuk kalimat, tabel, grafik, dan lain sebagainya.38 Ketiga, penarikan kesimpulan yaitu data yang diperoleh disimpulkan untuk menjawab fokus penelitian. Kesimpulan harus dapat menjawab masalah yang telah ditetapkan sebelumnya oleh peneliti. ${ }^{39}$ Adapun kisi-kisi penelitian dapat ditampilkan sebagai berikut:

Tabel 1

Kisi-Kisi Penelitian

\begin{tabular}{lll}
\hline Aspek & \multicolumn{2}{c}{ Indikator } \\
\hline Perencanaan & - Mampu menjelaskan perencanaan BOP PAUD \\
& - Mampu menjelaskan mengapa perencanaan BOP PAUD \\
& perlu dilakukan \\
& Mampu menjelaskan siapa yang melaksanakan \\
& perencanaan BOP PAUD \\
& Mampu menjelaskan bagaimana proses perencanaan BOP \\
& PAUD \\
\hline
\end{tabular}

34 Sugiyono, Metode Penelitian Kuantitatif, Kualitatif, dan R\&D, (Bandung: Alfabeta, 2015), 274.

35 Sugiyono, 274.

36 Sugiyono, 277.

37 Sugiyono, 247.

38 Sugiyono, 249.

39 Sugiyono, 252. 


\begin{aligned} & \hline Pengorganisasian Mampu menjelaskan pengorganisasian BOP PAUD \\ &- Mampu menjelaskan mengapa pengorganisasian BOP \\ & PAUD perlu dilaksankan \\ & Mampu menjelaskan siapa yang melaksanakan \\ & pengorganisasian BOP PAUD \\ & Mampu menjelaskan bagaimana hasil pengorganisasian \\ & BOP PAUD \\ & Pelaksanaan - Mampu menjelaskan pelaksanaan BOP PAUD \\ &- Mampu menjelaskan siapa yang melaksanakan BOP PAUD \\ & Pengontrolan - Mampu menjelaskan bagaimana pelaksanaan BOP PAUD \\ &- Mampu menjelaskan pengontrolan BOP PAUD menjelaskan siapa yang melakukan pengontrolan \\ & BOP PAUD \\ &- Mampu menjelaskan mengapa pengontrolan BOP PAUD \\ & Perlu dilakukan \\ & Mampu menjelaskan apa saja yang dikontrol dalam BOP \\ & \hline\end{aligned}

Adapun desain penelitian dalam penelitian ini dapat dijelaskan melalui gambar berikut:

\section{Gambar 2 Desain Penelitian}

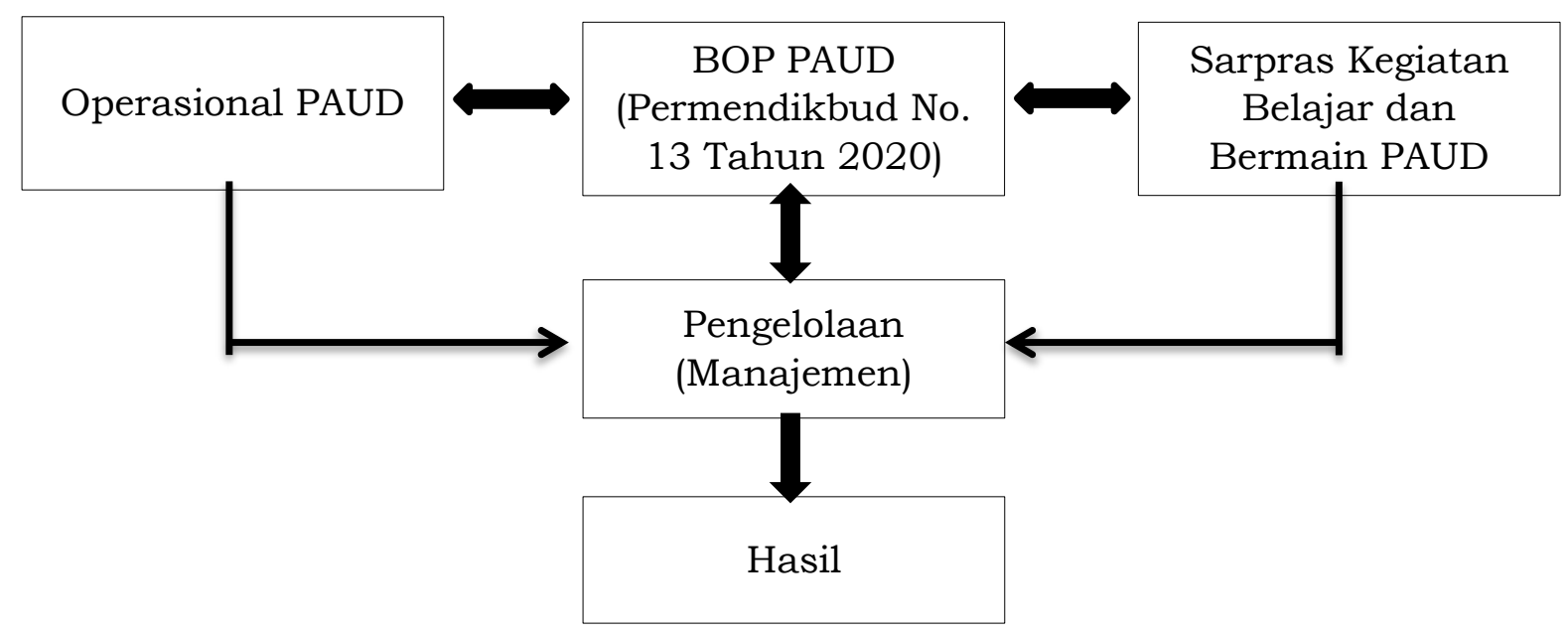

\section{Hasil \& Diskusi}

Hasil penelitian penelitian dapat ditampilkan dalam tabel matriks hasil penelitian sebagai berikut:

Tabel 2

Matriks Hasil Penelitian

Aspek Penelitian Hasil Penelitian $\quad$ Pengumpulan

Data

$\begin{array}{clcc}\text { Perencanaan } & \text { Merencanakan penggunaan dana BOP } & \text { Wawancara } \\ \text { BOP PAUD } & \begin{array}{l}\text { PAUD untuk kebutuhan proses } \\ \text { pendidikan di lembaga PAUD }\end{array} & & \text { Dokumentasi }\end{array}$




\begin{tabular}{clcc}
\hline & $\begin{array}{l}\text { Pembentukan tim pengelola BOP PAUD } \\
\text { Pengorganisasian } \\
\text { dan pengelompokan penggunaan dana }\end{array}$ & Wawancara \\
& $\begin{array}{l}\text { PAUD sesuai Permendikbud Nomor 13 } \\
\text { Tahun 2020 }\end{array}$ & Dokumentasi \\
& $\begin{array}{l}\text { Penggunaan dana BOP PAUD sesuai } \\
\text { dengan Permendikbud Nomor 13 Tahun }\end{array}$ & Wawancara \\
$\begin{array}{c}\text { Pelaksanaan } \\
\text { BOP PAUD }\end{array}$ & 2020 & & Dokumentasi \\
& $\begin{array}{l}\text { Pengecekan kesesuaian } \\
\text { dana BOP PAUD }\end{array}$ & Observasi \\
Pengontrolan & & & Wawancara \\
BOP PAUD & & Dokumentasi \\
\hline
\end{tabular}

Berdasarkan tabel 2 tetang matriks hasil penelitian, maka hasil penelitian dapat dibahas sebagai berikut:

A. Perencanaan BOP PAUD

Perencanaan adalah proses merancang atau mendisain suatu hal yang dijadikan sebagai acuan atau panduan bagi seseorang dan organisasi dalam melaksanakan suatu program atau kegiatan yang akan dikerjakan atau diselesaikan. Perencanaan merupakan proses mempersiapkan secara sistematis kegiatan yang akan dikerjakan pada waktu yang akan mendatang untuk mencapai tujuan dan sasaran yang telah ditentukan. ${ }^{40}$ Perencanaan BOP PAUD diartikan sebagai proses merencanakan pemanfaatan atau penggunaan dana BOP demi terpenuhinya segala kebutuhan proses pendidikan lembaga PAUD dalam satu periode tertentu. Perencanaan diartikan sebagai proses pengambilan keputusan atas sejumlah alternatif mengenai sasaran dan cara yang akan dilaksanakan di masa mendatang untuk mecapai tujuan yang dikehendaki. ${ }^{41}$

Perencanaan penggunaan BOP dilakukan dalam dua tahap. Pertama, tahap pra-penyaluran dana BOP yaitu dengan menganalisis penggunaan barang dan jasa berdasarkan pada pengalaman pemenuhuan kebutuhan sekolah sebelumnya. Kepala sekolah dan bendahara BOP melakukan pencatatan tentang pembelian barang dan jasa yang masih kurang (belum terpenuhi) pada tahun sebelumnya untuk dianggarkan atau diadakan pada tahun anggaran berikutnya. Misalnya untuk memenuhi Alat Peraga Edukatif (APE) luar PAUD seperti perosotan, ayunan, putaran fiber dan lain sebagainya. Karena dana yang kurang, maka kepala sekolah melalui bendahara mencatat APE apa saja yang telah terpenuhi dan yang belum terpenuhi untuk selanjutnya dianggarakan pada tahun anggaran berikutnya.

40 Muhammad Zaini, "Implementasi Fungsi Manajemen dalam Pengembangan Pendidikan Multikultural."

${ }^{41}$ Husaini Usman, Manajemen Teori, Praktik, dan Riset Pendidikan, (Jakarta: Bumi Aksara, 2011), 66. 
Kedua, perencanaan tahap pasca penyaluran Dana BOP. Lembaga PAUD yang telah menerima dana BOP diwajibkan menyerahkan Rencana Kerja dan Anggaran Sekolah (RKAS) dana BOP kepada Dinas Pendidikan setempat, dimana dalam RKAS tersebut sudah direncanakan atau dianggarkan untuk pembelian alat dan bahan kebersihan pencegahan virus Covid-19, pembelian paket data untuk guru selama pembelajaran dari rumah, serta honor tambahan bagi guru selama pembelajaran dari rumah. Kepala sekolah dan bendahara melakukan pengisian aplikasi RKAS dana BOP berdasarkan pada catatan pemenuhan atau pengadaan barang dan jasa PAUD yang sebelumnya telah dibuat dan kemudian disingkronkan dengan petunjuk teknis penggunaan dana BOP PAUD dari Kementerian Pendidikan Nasional atau disesuaikan dengan Permendikbud RI Nomor 13 Tahun 2020 tentang Juknis DAK Nonfisik Bantuan Operasional Penyelenggaraan PAUD dan Kesetaraan tahun anggaran 2020 yang didalamnya sudah terdapat penambahan penganggaran dana BOP untuk selama masa pandemi Covid19. Tujuan dari perencanaan tersebut untuk menjelaskan, menetapkan, dan memastikan tujuan yang dicapai, memperkirakan kondisi pekerjaan yang dilakukan, dan membuat rencana secara menyeluruh dengan menekankan kreativitas. ${ }^{42}$

B. Pengorganisasian BOP PAUD

Pengorganisasian merupakan kegiatan mengelompokkan atau mengorganisasikan suatu hal berdasarkan tugas, fungsi dan tanggung jawab dengan tujuan untuk mempermudah dan memperjelas tugas, fungsi, dan tanggungjawab dalam suatu program atau kegiatan tertentu yang akan dilaksanakan oleh seseorang atau organisasi. Pengorganisasian mengarah pada kegiatan pengaturan dan penetapan siapa yang menjadi pelaksana, penetapan anggaran, penetapan sarana dan prasarana, penetapan tata kerja, penetapan manajemen pelaksanaan termasuk pola kepemimpinan dan koordinasi pelaksanaan kebijakan. ${ }^{43}$ Pengoranisasian BOP PAUD diartikan sebagai proses mengelompokkan tugas atau wewenang pengelola dana BOP PAUD dan pengelompokan penggunaan dana BOP oleh lembaga PAUD. Pengorganisasian kebijakan sebagai proses pembagian tugas kerja menjadi beberapa unit kerja dengan tujuan untuk mempermudan dan mengorganisir tugas kerja implementasi yang harus diselesaikan oleh organisasi pendidikan. ${ }^{44}$

Pengorganisasian dana BOP oleh lembaga PAUD tersebut antara lain: Pertama, pengorganisasian pengelola dana BOP di lembaga PAUD yaitu pembentukan tim pengelola dana BOP pada lembaga PAUD yang terdiri atas penanggung jawab pengelolaan dan penggunaan dana BOP yang dijabat oleh

\footnotetext{
42 Awaluddin and Hendra, "Fungsi Manajemen Dalam Pengadaan Infrastruktur Pertanian Masyarakat Di Desa Watatu Kecamatan Banawa Selatan Kabupaten Donggala."

43 Joko Widodo, Analisis Kebijakan Publik: Konsep dan Aplikasi Analisis Proses Kebijakan Publik, (Malang: Bayumedia Publishing, 2012), 91.

44 Baidowi, "Implementasi Kebijakan Program Bantuan Operasional Penyelenggaraan Pendidikan Pada Masa Pandemi Covid-19."
} 
kepala sekolah PAUD dan bendahara dana BOP PAUD dijabat oleh guru PAUD yang bertanggung jawab untuk menyimpan dan menggunakan dana BOP. Pengorganisasian diartikan sebagai penataan, pengelompokan, pendistribusian tugas dan tanggung jawab serta wewenang pada masingmasing perangkat untuk menjadi kolektivitas yang dapat digerakkan sebagai teamwork dalam usaha mencapai tujuan. ${ }^{45}$ Tujuannya adalah membagi pekerjaan ke dalam tugas operasional, menggabungkan jabatan operasional ke dalam unit yang saling berkaitan, memilih dan menempatkan orang untuk suatu pekerjaan yang sesuai dan menyesuaikan wewenang dan tanggungjawab bagi anggota. 46

Kedua, pengorganisasian penggunaan dana BOP PAUD sesuai dengan Permendikbud Nomor 13 Tahun 2020 tentang Juknis DAK Nonfisik Bantuan Operasional Penyelenggaraan PAUD dan Kesetaraan yang dikelompokkan berdasarkan kegiatan pembelajaran dan bermain, untuk kegiatan pendukung PAUD dan untuk kegiatan lainnya yang terdapat di PAUD. Pembelian pulsa internet guru selama pembelajaran dari rumah dikelompokkan pada kegiatan pembelajaran dan bermain PAUD. Pembelian alat dan bahan kebersihan pencegahan penyebaran virus Covid-19 dan honor tambahan bagi tenaga pendidik selama pembelajaran dari rumah dikelompokkan pada kegiatan pendukung PAUD. Pengorganisasian sebagai proses penentuan, pengelompokan dan pengaturan berbagai aktivitas yang diperlukan untuk mencapai tujuan. ${ }^{47}$

C. Pelaksanaan BOP PAUD

Pelaksanaan merupakan segenap tindakan atau aksi yang dilakukan oleh seseorang atau organisasi untuk mengaplikasikan rencana yang telah dibuat sebelumnya. Implementasi sebagai tindakan yang dilakukan oleh individu atau kelompok pemerintah atau swasta yang diarahkan pada pencapaian tujuan yang telah ditentukan. ${ }^{48}$ Pelaksanaan BOP PAUD diartikan sebagai tindakan memanfaatkan atau menggunakan dana BOP untuk membeli atau mengadakan barang dan jasa demi kepentingan proses belajar mengajar pada PAUD. Implementasi sebagai serangkaian kegiatan yang dilakukan oleh organisasi pendidikan untuk menerapkan program kebijakan pendidikan yang dibuat oleh Kemeterian Pendidikan, Dinas Pendidikan, dan/atau oleh organisasi pendidikan lainnya. ${ }^{49}$ Maka pelaksanaan dana BOP dapat dijelaskan sebagai berikut:

45 Muhammad Zaini, "Implementasi Fungsi Manajemen dalam Pengembangan Pendidikan Multikultural."

46 Awaluddin and Hendra, "Fungsi Manajemen Dalam Pengadaan Infrastruktur Pertanian Masyarakat Di Desa Watatu Kecamatan Banawa Selatan Kabupaten Donggala."

47 Awaluddin and Hendra.

48 Mujianto, "Implementasi Kebijakan Pendidikan Dan Peran Birokrasi."

49 Baidowi, "Implementasi Kebijakan Program Bantuan Operasional Penyelenggaraan Pendidikan Pada Masa Pandemi Covid-19 Achmad Baidowi." 
Tabel 3

Penggunaan Dana BOP

\begin{tabular}{|c|c|c|c|}
\hline No & Uraian Kegiatan & Biaya & Waktu \\
\hline \multirow[t]{5}{*}{ I } & Kegiatan Pembelajaran dan Bermain & & \\
\hline & $\begin{array}{l}\text { 1. Bahan pembelajaran peserta dididk yang } \\
\text { dibutuhkan sesuai tematik }\end{array}$ & Rp. 2.200.000,00 & Jan - Jun 2020 \\
\hline & 2. Penyediaan Alat Permainan Edukatif (APE) & Rp. $1.600 .000,00$ & Jan - Jun 2020 \\
\hline & 3. Penyediaan alat pengajar bagi pendidik & Rp. $1.500 .000,00$ & Jan - Jun 2020 \\
\hline & $\begin{array}{l}\text { 4. Pembelian pulsa atau paket data bagi } \\
\text { tenaga pendidik dan peserta didik dalam } \\
\text { pelaksanaan pembelajarn dari rumah }\end{array}$ & Rp. $450.000,00$ & Apr - Jun 2020 \\
\hline \multirow{7}{*}{ II } & Kegiatan Pendukung & & \\
\hline & 1. Penyediaan makanan tambahan & Rp. $540.000,00$ & Jan - Jun 2020 \\
\hline & $\begin{array}{l}\text { 2. Kegiatan pertemuan dengan orang tua } \\
\text { murid (kegiatan parenting) }\end{array}$ & Rp. $360.000,00$ & Jan - Jun 2020 \\
\hline & 3. Memberi transport pendidik & Rp. $1.800 .000,00$ & Jan - Jun 2020 \\
\hline & 4. Penyediaan buku administrasi & Rp. $100.000,00$ & Jan - Jun 2020 \\
\hline & $\begin{array}{l}\text { 5. Pembiayaan honor pendidik dalam } \\
\text { pelaksanaan pembelajaran dari rumah }\end{array}$ & Rp. $450.000,00$ & Apr - Jun 2020 \\
\hline & $\begin{array}{l}\text { 6. Pembelian cairan atau sabun pembersih } \\
\text { tangan, pembasmi kuman (disinfektan, } \\
\text { masker, atau penunjang kebersihan } \\
\text { lainnya) }\end{array}$ & Rp. 950.000,00 & Apr - Jun 2020 \\
\hline \multirow[t]{5}{*}{ III } & Kegiatan Lainnya & & \\
\hline & 1. Perawatan sarana dan prasarana & Rp. $440.000,00$ & Jan - Jun 2020 \\
\hline & 2. Penyediaan alat-alat publikasi PAUD & Rp. $50.000,00$ & Jan - Jun 2020 \\
\hline & 3. Langganan listrik, telp / internet, air & Rp. $360.000,00$ & Jan - Jun 2020 \\
\hline & Total & Rp. $10.800 .000,00$ & \\
\hline
\end{tabular}

Penggunaan dana BOP adalah untuk memenuhi kebutuhan PAUD pada komponen pembelajaran dan bermain anak yang meliputi: pembelian bahan pembelajaran, penyediaan APE dan penyediaan alat mengajar PAUD; memenuhi komponen kegiatan pendukung PAUD yang meliputi: penyediaan makan anak, pembelian alat dan bahan kesehatan PAUD, kegiatan parenting, transport pendidik dan buku administrasi PAUD; serta memenuhi komponen kegiatan lainnya yang meliputi: pemeliharaan sarana dan prasarana PAUD, alat dan media publikasi PAUD dan langganan listrik, air dan internet PAUD (Permendikbud Nomor 13 tahun 2020 tentang Juknis BOP). Pengaplikasian kebijakan program BOP PAUD di masa pandemi Covid-19 berkaitan dengan penggunaan dana BOP untuk mendukung proses pembelajaran dan operasional sekolah selama masa pandemi Covid-19 dengan membelanjakan alat dan bahan kebersihan pencegahan penyebaran virus Covid-19, 
pembelanjaan pulsa atau paket data bagi guru, dan pemberian honor tambahan bagi guru selama pembelajaran daring. ${ }^{50}$

D. Pengontrolan BOP PAUD

Pengontrolan merupakan kegiatan mengecek atau me-review kembali kegiatan yang telah dilaksakan oleh seseorang atau organisasi dengan tujuan untuk menilai apakah pelaksanaan suatu kegiatan atau program telah berjalan sesuai dengan rencana dan tujuan yang telah tentukan sebelumnya. Pengontrolan berarti meneliti dan mengawasi agar tugas dapat dilakukan dengan baik dan sesuai dengan peraturan yang ada. ${ }^{51}$ Pengontrolan BOP PAUD diartikan sebagai kegiatan mengecek kesesuaian penggunaan dana BOP pada lembar Rencana Kerja dan Anggaran Sekolah (RKAS) PAUD dengan Permendikbud Nomor 13 Tahun 2020 tentang Juknis DAK Non-fisik Bantuan Operasional Penyelenggaraan PAUD dan Kesetaraan.

Pengecekan dilakukan oleh sekolah dan Dinas Pendidikan setempat dengan melihat atau meninjau kembali kenormalan penggunaan jumlah dana yang dianggarkan dalam memenuhi kebutuhan proses pendidikan pada masing-masing komponen kegiatan PAUD. Jika dana yang dianggarkan oleh lembaga PAUD tidak normal (misalnya terlalu banyak atau terlalu sedikit pada salah satu komponen kegiatan PAUD), maka Dinas Pendidikan perlu mengembalikan RKAS pada lembaga PAUD untuk selanjutnya dilakukan revisi atau perbaikan penganggaran dana BOP. Pengontrolan juga dilakukan dengan meninjau posisi atau letak pembelanjaan barang dan jasa untuk kebutuhan pembelajaran dari rumah selama masa pandemi Covid-19 dalam RKAS agar sesuai dengan petunjuk yang telah diberikan. Mengontrol berarti mengawasi atau memantau tugas yang dilaksanakan sekaligus memberikan evaluasi dan perbaikan sehingga pelaksanaan tugas sesuai dengan rencana yang ditetapkan. ${ }^{52}$

\section{Kesimpulan}

Berdasarkan hasil penelitian yang telah dipaparkan pada pembahasan, maka dapat disimpulkan bahwa fungsi manajemen dalam pengelolaan dana BOP PAUD dapat dikatakan sebagai proses merencanakan, mengorganisasikan, melaksanakan, serta mengontrol pengelolaan dana BOP pada lembaga PAUD. Merencanakan diartikan sebagai pembuatan rencana penggunaan dana BOP untuk memenuhi kebutuhan proses pendidikan PAUD. Mengorganisasikan diartikan sebagai proses pembentukan pengelola dana BOP pada lembaga PAUD serta pengelompokan penggunaan dana BOP sesuai dengan peraturan pemerintah. Melaksanakan diartikan sebagai tindakan menggunakan dana BOP untuk membeli atau mengadakan barang dan jasa demi kepentingan proses pendidikan di lembaga PAUD. Sedangkan pengontrolan diartikan sebagai proses pengecekan kembali penggunaan dana BOP yang telah dituangkan dalam Rencana Kerja Anggaran Sekolah (RKAS) BOP yang dibuat oleh lembaga PAUD. Saran bagi peneliti yang ingin

50 Baidowi.

51 Saefullah U, Manajemen Pendidikan Islam, (Bandung: Pustaka Setia, 2012), 38.

52 Muhammad Zaini, "Implementasi Fungsi Manajemen dalam Pengembangan Pendidikan Multikultural." 
meneliti tentang BOP, sebaiknya lakukan penelitian tentang evaluasi penggunaan dana BOP, sehingga kita dapat melihat sejauh mana penggunaan dan dampak dana BOP terhadap peningkatan kualitas pendidikan pada lembaga PAUD.

\section{Referensi}

Awaluddin, \& Hendra. (2018). Fungsi Manajemen Dalam Pengadaan Infrastruktur Pertanian Masyarakat Di Desa Watatu Kecamatan Banawa Selatan Kabupaten Donggala. Jurnal Fakultas Ilmu Sosial Dan Ilmu Politik Universitas Tadulako Indonesia, 2(1), 1-12.

Baidowi, A. (2020). Implementasi Kebijakan Program Bantuan Operasional Penyelenggaraan Pendidikan pada Masa Pandemi Covid-19. Jambura Journal of Educational Management, 1(2), 84-102.

Maujud, F. (2018). Implementasi Fungsi-Fungsi Manajemen dalam Lembaga Pendidikan Islam (Studi Kasus Pengelolaan Madrasah Ibtidaiyah Islahul Muta'allim Pagutan). Jurnal Penelitian Keislaman, 14(1), 30-50. doi: 10.20414/jpk.v14i1.490

Nurkholis. (2013). Pendidikan Dalam Upaya Memajukan Teknologi. Jurnal Kependidikan, 1(1), 24-44. Retrieved from http://ejournal.iainpurwokerto.ac.id/index.php/jurnalkependidikan/article/d ownload/530/473/

Peraturan Menteri Pendidikan dan Kebudayaan Nomor 13 Tahun 2020 tentang Petunjuk Teknis Dana Alokasi Khusus Nonfisik Bantuan Operasional Penyelenggaraan Pendidikan Anak Usia Dini dan Pendidikan Kesetaraan Tahun Anggaran 2020

Qudsyi, Hazhira. (2010). Optimalisasi Pendidikan Anak Usia Dini Berdasarkan Pembelajaran Yang Berbasis Perkembangan Otak. Buletin Psikologi, 18(2), 91111. doi: 10.22460/ceria.v2i2.p29-36

Ridho, R., Markhamah, \& Darsinah. (2015). Pengelolaan Pembelajaran Paud. Penelitian Humaniora, 16(02), 59-69. doi: 10.31102/wacanadidaktika.v5i02.63

Saefullah, U. (2012). Manajemen Pendidikan Islam. Bandung: CV. Pustaka Setia.

Sianturi, P., Mesran, M., Ramadhani, P., \& Al-Hafiz, N. W. (2017). Sistem Pendukung Keputusan Penentuan Penerima Bantuan Operasional Penyelengaraan (BOP) Paud (Pendidikan Anak Usia Dini) Menerapkan Metode ELECTRE (Studi Kasus : Dinas Pendidikan Kabupaten Simalungun). KOMIK (Konferensi Nasional Teknologi Informasi Dan Komputer), I(1), 20-26.

Solichin, Mujito. (2015). Implementasi Kebijakan Pendidikan Dan Peran Birokrasi. Studi Islam, 6(2), 148-178.

Sugiyono. (2015). Metode Penelitian Kuantitatif, Kualitatif, dan R\&D. bandung: Alfabeta

Suharti, S. (2018). Manajemen Pendidikan Anak Usia Dini (PAUD) dalam Rangka Meningkatkan Mutu Pembelajaran (Studi pada PAUD Negeri Pembina Curup dan PAUD Pertiwi Kabupaten Rejang Lebong). Tadbir: Jurnal Studi Manajemen Pendidikan, 2(1), 51. doi: 10.29240/jsmp.v2i1.397

Undang-Undang Dasar Republik Indonesia Nomor 20 Tahun 2003 tentang Sistem Pendidikan Nasional.

Usman, Husaini. (2011). Manajemen Teori, Praktik dan Riset Pendidikan. Jakarta: PT. Bumi Aksara.

Widodo, Joko. (2012). Analisis Kebijakan Publik: Konsep dan Aplikasi Analisis Proses Kebijakan Publik. Malang: Bayumedia Publishing.

Wijana, Widarmi D, W. (2014). Konsep-Konsep Dasar Pendidikan Anak Usia Dini. In 
Judul: Implementasi Fungsi Manajemen Pada Pengelolaan Program Bantuan Operasional PAUD di

Didaktika, Vol. 20 No. 2 Februari 2014 (Vol. 5, pp. 329-333). Retrieved from https:/ /www.google.com/url?sa=t\&source=web\&rct=j\&url=http: / / repository.u t.ac.id/4724/1/PAUD4409-M1.pdf\&ved=2ahUKEwi7vZGBk7rAhWWSHOKHZN4BzMQFjALegQIDRAC\&usg=AOvVaw3FE1r6418LV9BiL17K2 $\mathrm{dkL}$

Zaini, Muhammad. (2013). Implementasi Fungsi Manajemen dalam Pengembangan Pendidikan Multikultural. Edu Islamika, 04 (02), 281-315. 